\title{
Pengaruh Independensi, Pengalaman Kerja, Objektifitas dan Integritas Internal Auditor Terhadap Kualitas Audit (Survey Pada Bank Swasta Nasional Di Wilayah Jawa Barat)
}

\author{
Asep Kuswara \\ Fakultas Ekonomi, Universitas Nasional Pasim \\ Correspondence email: Akuswara2003@gmail.com
}

\begin{abstract}
Unqualified opinion (WTP) is a statement given oleh independent auditor. Such statement is proclaimed in froud manner and should be known by public. However, a sound statement given by the auditor does not necessarily mean that the organization is free from corruption, fraud or deceit. The purpose of this research is to examine the significance level of independence, working experience, objectivity and integrity to the audit quality, both partially and jointly. Survey with questionnaire was used during this research. collecting data through questionnaireson the interval auditor in national Banks headquartered in west Java.The sampling technique used purposive sampling approach. Samples were deployed in this study were 100 questionnaires in seven Bank is headquartered in West Java. Data analysis was performed by multiple regression model This study reveals that independent, working experience, objectivity and joint integrity affect audit quality. This study also reveals that partially, working experience and integrity have significance affect on audit quality, while independence and objectivity have little significance on the audit quality.
\end{abstract}

Keywords: independence, working experience, objectivity and integrity and audit quality.

\section{PENDAHULUAN}

Ada fenomena baru di media massa, yaitu munculnya iklan ucapan selamat kepada Kementerian/Lembaga dan Pemerintah Provinsi/Kabupaten/Kota atas opini Wajar Tanpa Pengecualian (WTP) yang diperoleh dari Badan Pemeriksa Keuangan Republik Indonesia (BPK-RI). Predikat ini seolah-olah membanggakan dan harus diketahui masyarakat. Bagi yang belum memahami kriteria pemberian opini, predikat itu bisa menjadi pencitraan positif, bahwa roda pemerintahan telah dikelola secara akuntabel bahkan bisa jadi terbebas dari korupsi (Kotot Gutomo, Auditor BPKP).

Fenomena yang terjadi di Kementerian Energi dan Sumber Daya Mineral (ESDM) mendapat opini Wajar Tanpa Pengecualian (WTP) atas laporan keuangan 2013. WTP adalah opini terbaik atau nilai sempurna yang diberikan Badan Pemeriksa Keuangan (BPK). Meski demikian, tetap saja Jero Wacik yang menjabat sebagai menteri saat itu tersandung kasus korupsi (Chatib Basri, Menteri Keuangan Era SBY).

Dalam tahun 2015, yang baru berjalan selama tiga bulan sudah ada tiga kasus pembobolan bank yang menjadi perhatian khalayak umum, dimulai dengan munculnya kasus pembobolan dana milik Bank Syariah Mandiri yang mencapai Rp50 miliar dengan modus menggunakan bilyet deposito palsu. Padahal pada tahun 2014 laporan keuangan Bank Syariah Mandiri (BSM) mendapat opini wajar tanpa pengecualian (WTP).

Kualitas audit yang dilakukan oleh auditor internal masih menjadi perhatian masyarakat. Hal ini disebabkan dari temuan pemeriksaan audit tersebut, tidak terdeteksi oleh Satuan Pengawas Intern (SPI) sebagai auditor internal. Akan tetapi ditemukan oleh Badan Pemeriksa Keuangan (BPK) sebagai auditor eksternal, ini menunjukkan bahwa kualitas audit internal dari SPI masih relatif kurang baik. (Ida Rosnidah dkk.,2011).

De Angelo (1981) mendefinisikan kualitas audit sebagai kemungkinan (joint probability) dimana seorang auditor akan menemukan dan melaporkan pelanggaran yang ada dalam sistem akuntansi kliennya, tapi pada kenyataannya kualitas audit yang dihasilkan auditor gagal dalam mendeteksi kecurangan didalam laporan keuangan Bank Syariah Mandiri (BSM).

Dalam kasus tersebut peran internal auditor tidak dapat di pungkiri, oleh karena itu dalam mengatasi penyimpangan yang terjadi peran pengawasan dari seorang internal auditor sangat diperlukan, untuk menghasilkan suatu kualitas audit yang baik diharapkan internal auditor untuk menerapkan dan menegakkan kode etik internal audit yaitu prinsip-prinsip Integritas, Objektivitas, Kerahasiaan dan Kompetensi (pengetahuan, kecakapan dan pengalaman) dan Standar Audit yang diperlukan dalam memberikan jasa audit internal.

\section{METODE}

Metode penelitian yang digunakan dalam penelitian ini adalah metode penelitian penjelasan (explanatory/confirmatory research), yaitu Penelitian yang dilakukan untuk menjelaskan dan mempertimbangkan informasi deskriptif. Ini dilakukan untuk mencari alasan atas sesuatu, menunjukkan mengapa dan bagaimana sesuatu itu, karena penelitian ini bermaksud untuk menjelaskan hubungan kausal antara variabel-variabel dengan melalui pengujian hipotesis yang telah dirumuskan sebelumnya.

\section{Operasional Variabel}

Independensi 
Menurut Standar Audit internasional (IPPF) section 1100 (2012) Independensi adalah kondisi bebas dari situasi yang dapat mengancam kemampuan aktivitas auditor internal untuk dapat melaksanakan tanggung jawabnya secara tidak memihak. Berdasarkan Sawyer's (2006) Indikator yang digunakan untuk mengukur independensi dalam penelitian ini adalah:

1. Independensi penyusunan Program

2. Independensi pelaksanaan pekerjaan

3. Independensi pelaporan

Selanjutnya Independensi akan dioperasionalkan oleh $X_{1}$ atau disebut juga sebagai variabel independen.

\section{Pengalaman Kerja}

Penagalaman kerja adalah pengalaman kerja auditor dalam melakukan audit laporan keuangan baik dari segi lamanya waktu, maupun banyaknya penugasan yang pernah dilakukan (Jeffry 1996) dalam (Sabrina 2012). Pengalaman kerja dalam penelitian ini menggunakan Indikator yang digunakan oleh Sukriah, Akram dan Inapty (2009) adalah :

1. Lamanya bekerja sebagai auditor

2. Banyaknya tugas pemeriksaan

Selanjutnya Pengalaman Kerja akan dioperasionalkan oleh $\mathrm{X}_{2}$ atau disebut juga sebagai variabel independen

\section{Obyektifitas}

Obyektifitas adalah suatu kualitas yang memberikan nilai atas jasa yang diberikan anggota. Prinsip obyektifitas mengharuskan anggota bersikap adil, tidak memihak, jujur serta intelektual, tidak berprasangka atau bias, serta bebas dari benturan kepentingan atau berada dibawah pengaruh pihak lain. (Prinsip etika, Kode etik IAI). Obyektifitas dalam penelitian ini menggunakan Indikator yang digunakan oleh Sukriah, Akram dan Inapty (2009) adalah :

1. Bebas dari benturan kepentingan

2. Pengungkapan kondisi sesuai fakta

Selanjutnya Objektifitas akan dioperasionalkan oleh $\mathrm{X}_{3}$ atau disebut juga sebagai variabel independen.

\section{Integritas}

Integritas adalah sikap jujur, berani, bijaksana dan tanggung jawab auditor dalam melaksanakan audit. (Kode Etik dan Standar audit Pusdiklatwas BPKP. 2008:21). integritas dalam penelitian ini menggunakan Indikator yang digunakan oleh Sukriah, Akram dan Inapty (2009) adalah :

1. Kejujuran auditor

2. Keberanian auditor

3. Sikap bijaksana auditor

4. Tanggung jawab auditor

Selanjutnya Integritas akan dioperasionalkan oleh $\mathrm{X}_{4}$ atau disebut juga sebagai variabel independen.

\section{Kualitas Audit}

Kualitas audit adalah kemungkinan (probability) dimana auditor akan menemukan dan melaporkan pelanggaran yang ada dalam sistem akuntansi klien. De Angelo (1981). Berdasarkan penelitian yang dilakukan oleh Justinia Castellani (2008) Indikator yang digunakan untuk mengukur kualitas audit dalam penelitian ini adalah:

1. Perencanaan

2. Pelaksanaan

3. Administrasi akhir

4. Kemampuan menemukan kesalahan

5. Keberanian melaporkan kesalahan Selanjutnya Kualitas Audit akan dioperasionalkan oleh $\mathrm{Y}$ atau disebut juga sebagai variabel dependen.

\section{Populasi dan Sampel}

Populasi dalam penelitian ini adalah Bank yang berkantor pusat di Jawa Barat dengan unit analisisnya adalah auditor internal. Sampel adalah sebagian atau wakil dari populasi yang akan diteliti. Sampel yang akan diteliti dianggap mewakili keberadaan populasi.

Tabel 1. Auditor Internal di Bank yang berkantor pusat di Jawa Barat

\begin{tabular}{|l|l|c|}
\hline No. & \multicolumn{1}{|c|}{ Nama Bank } & E Auditor Internal \\
\hline 1 & $\begin{array}{l}\text { PT. Bank Pembangunan } \\
\text { Daerah Jabar dan Banten } \\
\text { Tbk (BJB) }\end{array}$ & 44 \\
\hline 2 & $\begin{array}{l}\text { PT Bank Nusantara } \\
\text { Parahyangan Tbk (BNP) }\end{array}$ & 30 \\
\hline 3 & $\begin{array}{l}\text { PT Bank Bisnis } \\
\text { Internasional }\end{array}$ & 4 \\
\hline 4 & PT Bank Artos Indonesia & 5 \\
\hline 5 & PT Bank Fama Internasional & 4 \\
\hline 6 & $\begin{array}{l}\text { PT Bank Himpunan Saudara } \\
\text { 1906 Tbk }\end{array}$ & 9 \\
\hline 7 & Bank BJB Syariah & 4 \\
\hline & Jumlah & 100 \\
\hline
\end{tabular}

Sumber Pengolahan Data

\section{Metode Pengumpulan Data}

Pengumpulan data yang dilakukan adalah dengan menggunakan metode survey (survey method), yaitu menyebarkan daftar pertanyaan (kuesioner) yang akan diisi atau dijawab oleh responden auditor dan staf/pejabat pemeriksa Masing-masing Bank diberikan kuesioner dengan jangka waktu pengembalian 2 (dua) minggu terhitung sejak kuesioner diterima oleh responden. Jawaban dari pernyataan dalam kuesioner tersebut telah ditentukan skornya berdasarkan skala Likert 5 poin.

\section{Metode Analisis Data}

Analisis statistik yang digunakan untuk pengujian hipotesis dalam penelitian ini yaitu analisis regresi linier berganda dengan terlebih dahulu melakukan uji asumsi 
Asep Kuswara, Pengaruh Independensi, Pengalaman Kerja, Objektifitas dan Integritas Internal Auditor Terhadap Kualitas Audit (Survey Pada Bank Swasta Nasional Di Wilayah Jawa Barat)

klasik. Uji Asumsi Klasik terdiri dari Uji Normalitas, Uji Multikolinearitas, Uji Autokorelasi dan Uji Heteroskedastisitas.

\section{Analisis Regresi Linier Berganda}

Digunakan untuk mengetahui ada atau tidaknya pengaruh variabel bebas terhadap variabel terikat. Analisis ini digunakan untuk menjawab bagaimana pengaruh independensi, pengalaman kerja, obyektifitas dan integritas terhadap kualitas audit. Rumus yang digunakan dalam analisis regresi linear berganda adalah sebagai berikut:

$$
Y=a+b_{1} X_{1}+b_{2} X_{2}+e
$$

\section{Uji Hipotesis}

Penelitian ini akan menguji pengaruh variabel independen yang terdiri dari independensi, pengalaman kerja, obyektifitas dan integritas terhadap variable dependen yaitu kualitas audit. Alat uji yang digunakan untuk menguji hubungan variabel tersebut adalah uji $t$ dan uji F.

\section{Uji t}

Uji $\mathrm{t}$ bertujuan untuk menguji apakah variabel independen (independensi, pengalaman kerja, obyektifitas serta integritas) berpengaruh secara parsial atau individual terhadap variabel dependen (kualitas audit)

Menentukan $\mathrm{t}_{\text {hitung }}$ perumusannya sebagai berikut :

$$
\begin{aligned}
& \text { thitung }=\frac{b_{i}-\left(\beta_{i}\right)}{s b}=\beta_{i}=0 \text { dengan rumus } \\
& \text { thitung }=\frac{b_{1}}{s_{b}}
\end{aligned}
$$

Dimana :

$b_{i}=$ Koefisien Variabel ke-i

$\beta_{\mathrm{i}}=$ Parameter ke-1 yang dihipotesiskan

$\mathrm{Sb}=$ Kasalahan standar adalah standar error dari koefisien regresi.

Menentukan kriteria penerimaan dan penolakan Ho

Jika probabilitas $<0,05$ tolak Ho

Jika probabilitas $>0,05$ diterima Ho

\section{Uji F}

Uji F dilakukan untuk menguji kebenaran hipotesis alternatif, yaitu bahwa model pilihan peneliti sudah tepat/signifikan atau tidak tepat/non signifikan. Untuk menentukan nilai $\mathrm{F}$ ( $\left.F_{\text {hitung }}\right)$ perumusannya sebagai berikut :

$$
F=\frac{\frac{R^{2}}{2}}{\frac{\left(1-R^{2}\right.}{\left(n-k_{1}\right)}}
$$

Keterangan :

$\mathrm{R}^{2}=$ Koefisien determinasi

$\mathrm{n} \quad=$ Jumlah sampel

$\mathrm{k}-\quad=$ Jumlah variabel independent

Menentukan kriteria penerimaan dan penolakan

Ho, dengan melihat tingkat probabilitasnya, yaitu :

Jika probabilitas $<0,05$ tolak Ho

Jika probabilitas $>0,05$ diterima Ho

\section{HASIL DAN PEMBAHASAN \\ Data Responden}

Penelitian ini menggunakan instrumen kuesioner dengan objek penelitian auditor internal pada Bank Nasional yang berkantor pusat di wilayah Jawa Barat. Total kuesioner yang disebarkan ke Bank Nasional yang berkantor pusat di wilayah Jawa Barat 100 kuesioner. Kuesioner yang kembali tujuh puluh satu kuesioner dan dianalisis secara statistik untuk memperoleh hasil pengujian hipotesis

Tabel 2 Tanggapan Responden

\begin{tabular}{|c|c|c|c|c|c|c|c|c|}
\hline \multirow{2}{*}{$\begin{array}{c}\text { No. } \\
\text { Item }\end{array}$} & \multicolumn{8}{|c|}{ Alternatif Jawaban } \\
\cline { 2 - 9 } & Tidak pernah & \multicolumn{2}{|c|}{ Jarang } & \multicolumn{2}{c|}{ Kadang } & \multicolumn{2}{c|}{ Sering } \\
\cline { 2 - 9 } & $\mathbf{F}$ & $\mathbf{\%}$ & $\mathbf{F}$ & $\mathbf{\%}$ & $\mathbf{F}$ & $\mathbf{\%}$ & $\mathbf{F}$ & $\mathbf{\%}$ \\
\hline 1 & 7 & 9.9 & 0 & 0.0 & 8 & 11.3 & 21 & 29.6 \\
\hline 2 & 0 & 0.0 & 0 & 0.0 & 1 & 1.4 & 21 & 29.6 \\
\hline 3 & 0 & 0.0 & 0 & 0.0 & 1 & 1.4 & 25 & 35.2 \\
\hline & $\mathbf{7}$ & $\mathbf{3 . 3}$ & $\mathbf{0}$ & $\mathbf{0 . 0}$ & $\mathbf{1 0}$ & $\mathbf{4 . 7}$ & $\mathbf{6 7}$ & $\mathbf{3 1 . 5}$ \\
\hline
\end{tabular}

\begin{tabular}{|c|c|c|c|c|c|}
\hline \multirow{2}{*}{$\begin{array}{c}\text { No. } \\
\text { Item }\end{array}$} & \multicolumn{2}{|c|}{ Alternatif Jawaban } & \multirow{2}{*}{$\begin{array}{c}\text { Skor } \\
\text { Aktual }\end{array}$} & $\begin{array}{c}\text { Skor } \\
\text { Ideal }\end{array}$ & \multirow{2}{*}{} \\
\cline { 2 - 3 } & $\mathbf{F}$ & $\mathbf{\%}$ & & & \\
\hline 1 & 35 & 49.3 & 290 & 355 & 81.7 \\
\hline 2 & 49 & 69.0 & 332 & 355 & 93.5 \\
\hline 3 & 45 & 63.4 & 328 & 355 & 92.4 \\
\hline & $\mathbf{1 2 9}$ & $\mathbf{6 0 . 6}$ & $\mathbf{9 5 0}$ & $\mathbf{1 0 6 5}$ & $\mathbf{8 9 . 2}$ \\
\hline
\end{tabular}

Tanggapan responden mengenai Independensi diperoleh skor actual 950 dengan skor ideal yang dicapai sebesar 1065. Hasil perbandingan antara skor ideal dengan actual yang telah dicapai tersebut, memberikan perolehan nilai presentase $89,2 \%$. Nilai ini berada dalam kelas interval antara $84,01 \%$ - $100 \%$ dengan katagori sangat baik.

Tanggapan responden mengenai Pengalaman Kerja diperoleh skor aktual 637 dengan skor ideal yang dicapai sebesar 710. Hasil perbandingan antara skor ideal dengan actual yang telah dicapai tersebut, memberikan perolehan nilai presentase $89,7 \%$. Nilai ini berada dalam kelas interval antara 84,01\% - 100\% dengan katagori sangat baik.

Tanggapan responden mengenai Objektifitas diperoleh skor actual 644 dengan skor ideal yang dicapai sebesar 710. Hasil perbandingan antara skor ideal dengan aktual yang telah dicapai tersebut, memberikan perolehan nilai presentase $90,7 \%$. Nilai ini berada dalam 
kelas interval antara $84,01 \%$ - $100 \%$ dengan katagori sangat baik.

Tanggapan responden mengenai Integritas diperoleh skor aktual 1374 dengan skor ideal yang dicapai sebesar 1420. Hasil perbandingan antara skor ideal dengan aktual yang telah dicapai tersebut, memberikan perolehan nilai presentase $96,8 \%$. Nilai ini berada dalam kelas interval antara 84,01\% - 100\% dengan katagori sangat baik.

Tanggapan mengenai kualitas audit diperoleh skor actual 1678 dan skor ideal yang dicapai sebesar 1775 . Hasil perbandingan antara skor ideal dengan actual yang telah dicapai tersebut memberikan perolehan nilai presentase $94,5 \%$. Nilai ini berada dalam kelas interval antara 84,01 \% - 100\% dengan katagori baik.

\section{Analisa Regresi Berganda}

Hasil pengelohan software SPSS 20 untuk analisa regresi berganda disajikan pada table berikut :

Tabel 3. Analisa Regresi Berganda

\begin{tabular}{|l|l|c|l|c|}
\hline \multicolumn{1}{|c|}{ Variabel } & $\begin{array}{c}\text { Koefisien } \\
\text { Regresi }\end{array}$ & $\begin{array}{c}\text { Std. } \\
\text { Error }\end{array}$ & $\mathbf{t}$ & Sig. \\
\hline (constant) & $-2,193$ & 1,722 & $-1,273$ & 0,000 \\
\hline Independensi & 0,332 & 0,169 & 1,970 & 0,053 \\
\hline Pengalaman & 0,621 & 0,227 & 2,732 & 0,008 \\
\hline Objektifitas & 0,306 & 0,200 & 1,529 & 0,131 \\
\hline Integritas & 0,687 & 0,194 & 3,535 & 0,001 \\
\hline
\end{tabular}

Sumber : Pengolahan Data

Berdasarkan hasil perhitungan pada tabel di atas, diperoleh bentuk persamaan regresi linier berganda sebagai berikut :

\section{$\widehat{Y}=-2,193+0,332 X_{1}+0,621 X_{2}+0,306 X_{3}+0,687 X_{4}$}

Dari persamaan regresi linier berganda diatas diperoleh nilai konstanta sebesar -2,193. Artinya, jika variabel Kualitas Audit (Y) tidak dipengaruhi oleh keempat variabel bebasnya yaitu Indepedensi $\left(\mathrm{X}_{1}\right)$, Pengalaman Kerja $\left(\mathrm{X}_{2}\right)$, Objektivitas $\left(\mathrm{X}_{3}\right)$ dan Integritas $\left(\mathrm{X}_{4}\right)$ bernilai nol, maka besarnya rata-rata Kinerja akan bernilai -2,193.

Tanda koefisien regresi variabel bebas menunjukkan arah hubungan dari variabel yang bersangkutan dengan Kualitas Audit. Koefisien regresi untuk variabel bebas $\mathrm{X}_{1}$ bernilai positif, menunjukkan adanya hubungan yang searah antara Indepedensi $\left(\mathrm{X}_{1}\right)$ dengan Kualitas Audit (Y). Koefisien regresi variabel $\mathrm{X}_{1}$ sebesar 0,332 mengandung arti untuk setiap pertambahan Independensi $\left(\mathrm{X}_{1}\right)$ sebesar satu persen akan menyebabkan meningkatnya Kualitas Audit (Y) sebesar 0,332. Berdasarkan hasil pengujian hipotesis dapat disimpulkan bahwa Independensi berpengaruh terhadap Kualitas Audit.

Koefisien regresi untuk variabel bebas $\mathrm{X}_{2}$ bernilai positif, menunjukkan adanya hubungan yang searah antara Pengalaman Kerja $\left(\mathrm{X}_{2}\right)$ dengan Kualitas Audit $(Y)$. Koefisien regresi variabel $\mathrm{X}_{2}$ sebesar 0,621 mengandung arti untuk setiap pertambahan Pengalaman Kerja $\left(X_{2}\right)$ sebesar satu persen akan menyebabkan meningkatnya Kualitas Audit (Y) sebesar 0,621. Berdasarkan hasil pengujian hipotesis dapat disimpulkan bahwa Pengalaman kerja berpengaruh signifikan terhadap Kualitas Audit

Koefisien regresi untuk variabel bebas $\mathrm{X}_{3}$ bernilai positif, menunjukkan adanya hubungan yang searah antara Objektivitas $\left(\mathrm{X}_{3}\right)$ dengan Kualitas Audit $(\mathrm{Y})$. Koefisien regresi variabel $\mathrm{X}_{3}$ sebesar 0,306 mengandung arti untuk setiap pertambahan Objektivitas $\left(\mathrm{X}_{3}\right)$ sebesar satu persen akan menyebabkan meningkatnya Kualitas Audit (Y) sebesar 0,306. Berdasarkan hasil pengujian hipotesis dapat disimpulkan bahwa Objektifitas berpengaruh signifikan terhadap Kualitas Audit

Koefisien regresi untuk variabel bebas $\mathrm{X}_{4}$ bernilai positif, menunjukkan adanya hubungan yang searah antara Integritas $\left(\mathrm{X}_{4}\right)$ dengan Kualitas Audit (Y). Koefisien regresi variabel $\mathrm{X}_{4}$ sebesar 0,687 mengandung arti untuk setiap pertambahan Integritas $\left(\mathrm{X}_{4}\right)$ sebesar satu persen akan menyebabkan meningkatnya Kualitas Audit (Y) sebesar 0,687. Berdasarkan hasil pengujian hipotesis dapat disimpulkan bahwa Integritas berpengaruh signifikan terhadap Kualitas Audit.

\section{SIMPULAN}

Berdasarkan hasil pengujian hipotesis dan mengacu pada perumusan serta tujuan dari penelitian ini, maka dapat ditarik kesimpulan-kesimpulan sebagai berikut:

1. Hasil penelitiian ini menunjukan Independensi berpengaruh terhadap kualitas audit, independensi yang masih kurang baik dikarenakan masih adanya campur tangan dari pimpinan/ inspektur untuk menentukan, mengeliminasi atau memodifikasi bagian-bagian tertentu yang akan diperiksa serta terdapat intervensi atas prosedur yang dipilih oleh auditor.

2. Pengalaman kerja mempunyai pengaruh yang signifikan terhadap kualitas audit, adanya judgement professional dari auditor yang masih kurang baik dikarenakan auditor masih kurang pengalaman baik dalam banyaknya tugas audit yang dilakukan maupun variasi pemeriksaan atau kompleksitas transaksi keuangan perusahaan yang diaudit sehingga akan menambah dan memperluas pengetahuannya di bidang akuntansi dan auditing

3. Hasil penelitian ini menunjukan Obyektifitas auditor mempunyai pengaruh terhadap kualitas audit, objektifitas yang kurang baik terjadi karena masih adanya benturan kepentingan hal ini disebabkan auditor sikapnya masih tidak netral, tidak adil dan terjebak dalam pertentangan kepentingan dalam pemeriksaannya. 
4. Dalam penelitian ini Integritas berpengaruh signifikan terhadap kualitas audit, integritas yang masih kurang terjadi karena auditor masih ada kurang memiliki rasa percaya diri yang besar dalam menghadapi berbagai kesulitan, auditor mengemukakan hal-hal yang menurut pertimbangan dan keyakinannya masih kurang dilakukan dan Auditor masih dapat diintimidasi oleh orang lain dan kurang tunduk karena ada tekanan yang dilakukan oleh orang lain guna mempengaruhi sikap dan pendapatnya

5. Indepedensi, Pengalaman Kerja, Objektivitas dan Integritas secara bersama-sama memberikan pengaruh terhadap Kualitas Audit, sedangkan sisanya merupakan kontribusi variabel lain selain Indepedensi, Pengalaman Kerja , Objektivitas dan Integritas.

\section{DAFTAR PUSTAKA}

Achmat Badjuri, Faktor-Faktor Yang Berpengaruh Terhadap Kualitas Audit Auditor Independen Pada Kantor Akuntan Publik (Kap) Di Jawa Tengah, Dinamika Keuangan dan Perbankan Vol. 3, No. 2, Nopember 2011, Hal: 183 - 197

Al Materneh, Ghassan F. 2011. Factors Determining the Internal Audit Quality in Banks: Empirical Evidence from Jordan. International Research Journal of Finance and Economics, (Online), Issue 73.

Alim, M. Nizarul. Trisni Hapsari dan Lilik Purwanti. 2007. Jurnal. Pengaruh Kompetensi Dan Independensi Terhadap Kualitas Audit Dengan Etika Auditor Sebagai Variabel Moderasi. SNA X. Makassar.

Alvin A. Arens, Randal J. Elder and Mark S. Beasley, Auditing and Assurance Services and Integrated Approach, 14th edition Publisher: Pearson Prentice Hall @ 2012

Alvin A. Arens, Randal J. Elder and Mark S. Beasley, Auditing dan Jasa Assurance Pendekatan Terintegrasi Jilid 1, edisi 12 Penerbit Erlangga, Jakarta tahun 2008

Andy Dwi Cahyono, Andy Fefta Wijaya dan Tjahjanulin Domai, Pengaruh Kompetensi, Independensi, Obyektivitas, Kompleksitas Tugas, Dan Integritas Auditor Terhadap Kualitas Hasil Audit, REFORMASI ISSN 2088-7469 (Paper) ISSN 2407-6864 (Online) Vol. 5, No. 1, 2015, www.jurnal.unitri.ac.id.

Arens, Alvin A \& Loebbecke, James K. 2012. Auditing, an Integrated Approach. 14th Edition. Upper Saddle River, New Jersey: Prentice-Hall, Inc.

Bella Ariviana dan Haryanto, Pengaruh Akuntabilitas, Pengetahuan, Pengalaman, Dan Independensi Terhadap Kualitas Hasil Kerja Auditor (Studi Empiris pada KAP di Kota Semarang dan
Surakarta), Diponegoro Journal Of Accounting Volume 3, Nomor 2, Tahun 2014, Halaman 1-8, tahun 2014

De Angelo, L.E. 1981. Auditor Size and Auditor Quality. Journal of Accounting and Economics 3. Final Version received july 1981. p. 183-199.

Ghozali, Imam. 2013. Aplikasi Analisis Multivariate Dengan Program IBM SPSS 21 Update PLS Regresi Edisi 7. Penerbit BP Universitas Dipenogoro, Semarang

Gujarati, Damodar N, Dasar -Dasar Ekonometrika, edisi 5 tahun 2010, Penerbit Salemba.

Hekinus Manao, Modul Filosofi Auditing, PUSDIKLATWAS BPKP Tahun 2008

Icuk Rangga Bawono dan Elisha Muliani Singgih. 2010, Faktor-faktor dalam diri Auditor dan kualitas audit : Studi pada KAP Big Four di Indonesia. Symposium Nasional Akuntansi XIII Purwokerto 2010 Universitas Jenderal Sudirman Purwokerto.

J. Supranto, 2009. Statistik Teori dan Aplikasi, Edisi ketujuh Jilid 2 : Jakarta, Penerbit Erlangga.

Justinia Castellani, Kompetensi dan Independensi Auditor Pengaruhnya pada Kualitas Audit, Trikonomika Volume 7, No.2, Desember 2008, Hal. 114-121ISSN 1411-514X.

Kosasih, Ruchyat, 2000. Peranan dan Fungsi Internal Auditor, Edisi 3, PT Eresco, Bandung.

Melody Iskandar Dan Stefani Lily Indarto, Interaksi Independensi, Pengalaman, Pengetahuan, Due Professional Care, Akuntabilitas Dan Kepuasan Kerja Terhadap Kualitas Audit, 3rd Economics \& Business Research Festival 13 November 2014.

Mulya E. Siregar, Deputi Komisioner Pengawasan Perbankan (OJK); Majalah Stabilitas : Laporan Utama "Bahaya Laten Bernama Fraud" http://stabilitas.co.id/home/detail/bahaya-latenbernama-fraud Kamis 7 Mei 2015 21:2:0.

Precilia Prima Queena, Abdul Rohman. 2012 Analisis Faktor-Faktor Yang Mempengaruhi Kualitas Audit Aparat Inspektorat Kota/Kabupaten Di Jawa Tengah Diponegoro Journal Of Accounting Volume 1, Nomor 2, Tahun 2012, Halaman 1-12 http://ejournal-s1.undip.ac.id /index.php/accounting.

Putu Diana Aginia Lestari, Desak Made Werastuti, Edy Sujana, : Analisis Faktor-Faktor Yang Mempengaruhi Kualitas Audit Bpk Ri Perwakilan Provinsi Bali, e-Journal S1 Ak Universitas Pendidikan Ganesha Jurusan Akuntansi S1 (Volume 3 No. 1 Tahun 2015).

Pambudy, A. P., \& Syairozi, M. I. (2019). Analisis Peran Belanja Modal dan Investasi Swasta Terhadap Pertumbuhan Ekonomi Serta Dampaknya Pada Kesejahteraan Masyarakat. Jurnal Ekonomi dan Bisnis, 20(1), 26-39. 
Asep Kuswara, Pengaruh Independensi, Pengalaman Kerja, Objektifitas dan Integritas Internal Auditor Terhadap Kualitas Audit (Survey Pada Bank Swasta Nasional Di Wilayah Jawa Barat)

Redwan Jaafar dan, Sumiyati, Ak. Modul Kode Etik dan Standar Audit, PUSDIKLATWAS BPKP Tahun 2008.

Ridho Hidayat, Andreas dan Elfi Ilham : Pengaruh pengalaman kerja, etika, integritas, dan motivasi terhadap kualitas audit (Studi empiris pada auditor BPKP Provinsi Riau), JOM FEKON Vol. 1 No.2 Oktober 2014.

Robert Tampubolon "Risk and system-Based Internal Auditing" Penerbit Elex Media Komputindo, Jakarta (2005).

Sabrina K. dan Indira Januarti, (2011), Pengaruh Pengalaman, Keahlian, Situasi Audit, Etika Dan Gender Terhadap Ketepatan Pemberian Opini Auditor Melalui Skeptisisme Profesional Auditor (Studi Kasus Pada KAP Big Four di Jakarta).

Sawyer, Lawrence B., Dittenhofer, Mortimer A., Scheiner, James H. "Sawyer's Internal Audit", Buku 1 Published by The Institute of Internal Auditors, Penerbit Salemba Empat (2006).

Sawyer, Lawrence B., Dittenhofer, Mortimer A., Scheiner, James H., Graham, Anne. (Contributor)/ Makosz, Paul (Contributor), "Sawyer's Internal Auditing : The Practice of Modern Internal Auditing" Published by Inst of Internal Auditors (2012).

Standar Profesional Akuntan Publik, (SPAP) PSA no. 33 (2004:322.1) Pertimbangan Auditor Atas Fungsi Audit Intern dalam Audit Laporan Keungan.

Steven Balsam, Jagan Krishnan, and Joon S. Yang "Auditor Industry Specialization and Earnings Quality" Auditing: A Journal Of Practice \& Theory Vol. 22, No. 2 September 2003, pp. 71.97.

Sudarmo, Suwardi dan Agus Yulianto, Modul Fraud Auditing yang dikeluarkan oleh Pusdiklatwas BPKP tahun 2008.

Sugiyono. 2014. Metode Penelitian Bisnis. Cetakan keenam belas. Bandung: Alfabeta.

Suharsimi Arikunto. 2010. Prosedur Penelitian. Jakarta: Rineka Cipta.

Sukrisno Agus, 2013 AUDITING (Pemeriksaan Akuntan) oleh kantor akuntan Publik. Edisi Keempat. Jakarta Penerbit Fakultas Ekonomi Universitas Indonesia.

Sukriah, Ika. Akram dan Biana Adha Inapty. 2009, Pengaruh Pengalaman Kerja, Independen, Objektifitas, Integritas dan Kompetensi Terhadap Kualitas Hasil Pemeriksaan. SNA 12 Palembang Universitas Sriwijaya.

Supriyanto, Eko B. 2006. Budaya Kerja Perbankan, Jalan Lurus Menuju Integritas. Jakarta: LP3ES.

Susilawati, Maya R Atmawinata, Pengaruh Profesionalisme Dan Independensi Auditor Internal Terhadap Kualitas Audit: Studi Pada Inspektorat Propinsi Jawa Barat, Jurnal Etikonomi Vol. 13 No. 2 Oktober 2014 P 190 - 210.
The Institute of Internal Auditors' (IIA's) International Professional Practices Framework (IPPF) 2013 Edition.

Timothy J. Louwers (Author), Robert J. Ramsay (Author), David H. Sinason (Author), Jerry R. Strawser (Author), Jay C. Thibodeau (Author), Auditing \& Assurance Services, 5th Edition 5th Edition Publisher: Irwin/McGraw-Hill; 5th edition (February 1, 2012).

Trisnaningsih, Sri. 2007. Independensi Auditor dan Komitmen Organisasi sebagai Mediasi Pengaruh Pemahaman Good Governance, Gaya Kepemimpinan dan Budaya Organisasi Terhadap Kinerja Auditor. SNA X Makasar. AMKP-2.

Umi Narimawati, 2007. Riset Manajemen Sumber Daya Manusia. Pustaka Media.

Widiyanto, Joko, 2012, "SPSS For Windows Untuk Analisis Data Statistik dan Penelitian", Laboratorium Komputer FKIP Universitas Muhammadiyah Surakarta : Surakarta.

William C. Boynton, Raymond N. Johnson, August 2005, C2006, Modern Auditing: Assurance Services and the Integrity of Financial Reporting, 8th Edition. 